\title{
Poem: Dedicated to Andries G. van Aarde by Lina Spies
}

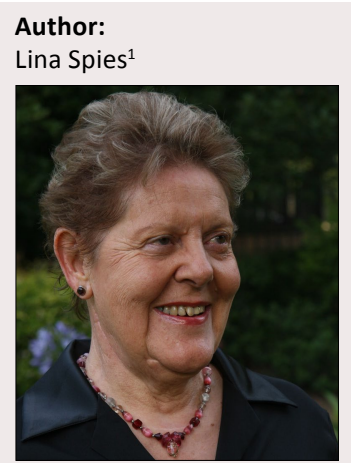

Affiliation:

${ }^{1}$ Department of Afrikaans and Dutch, Stellenbosch University, South Africa

\section{Correspondence to:}

Lina Spies

email:

linaspies@xsinet.co.za

Postal address:

PO Box 675, Stellenbosch 7599 , South Africa

How to cite this poem: Spies, L., 2011, 'Poem: Dedicated to Andries G. van Aarde by Lina Spies', HTS Teologiese Studies/ Theological Studies 67(1), Art. \#1041, 1 page. DOI: 10.4102/hts.v67i1.1041

(C) 2011. The Authors. Licensee: OpenJournals Publishing. This work is licensed under the Creative Commons Attribution License.

\section{Ontdaan}

Nee, dit was nie ' $n$ heilige nag nie;

dit was ' $n$ nag soos alle ander nagte.

Miskien was dit' $n$ sterligte nag

waarin dieselfde sterre

- soos die wette van die natuur bepaal -

geskyn het bo Galilea,

die oproerige provinsie

waarop die Romeine altyd ' $n$ wakende oog moes hou.

Nee, jy het nie - hoogswanger - die reis afgelê saam met Josef, die fiktiewe vader van jou ongebore kind, om jou te laat inskryf in die sensus

soos bepaal deur keiser Augustus nie;

vrouens het nie getel as inwoners van 'n land nie.

Nee, jy het nie gelyk soos die Italiaanse meesters jou later geskilder het nie-

die nakomelinge van Pontius Pilatus

wat daardie kind wat jy in skande moes baar toe hy êrens in sy dertigerjare was

veroordeel het tot die skanddood aan ' $n$ kruis.

Nee, jy het nie ' $n$ Fra Angelico-blou mantel gedra en bo jou hoof het geen stralekrans geskyn

toe' 'n sogenaamde engel jou die boodskap sou gebring het dat die kind wat jy gedra het die Seun van God was nie.

Nee, jy moes donker gewees het van huid en haar

- eie aan die volk waartoe jy behoort het -

en aan die vrug van jou skoot

moes jy soos alle uitgeworpenes swaar gedra het;

of hy uit ongeoorloofde liefde verwek is

of uit geoorloofde misbruik van' $n$ vrou.

Vaderloos in Galilea, het God van hom besit geneem sodat hy aan swakkes en geminagtes

die status van menswees kon gee;

sy hande op kinders kon lê

en vrouens na hom aan kon trek

onder wie hy jou nooit uitgesonder het

as die Moeder van God nie.

Ek was lank op reis na hom

maar eers toe die engelekore stil geword het

en ek sy stem kon hoor;

eers toe die geur van wierook en mirre verdamp het en ek die sweet en stof kon ruik

van sy tuistelose omswerwinge,

het ek my rug gedraai op die Kind van Bethlehem

en jou seun ontmoet, rabbi Jesjoea van Nasaret.

Lina Spies, 17 Mei 2008

Opgedra aan Andries van Aarde en gepubliseer in Tydelose gety, Protea Boekhuis, Pretoria, bl. 68-69, 2010; met toestemming van digter en uitgewer.

\section{Unsettled}

No, it was not a holy night;

it was a night like any other.

Maybe it was a starlit night

in which the same stars

- as the laws of nature decree -

shone over Galilee,

the unruly province

closely watched by the Romans.

No, you - heavily pregnant - did not travel the distance with Joseph, the fictitious father of your unborn child,

to be registered in the census

as ordered by Emperor Augustus;

women did not count as citizens of the land.

No, you did not look like the portraits Italian masters later painted of you -

the progeny of Pontius Pilate

who condemned the child you bore in shame when he was in his thirties

to a shameful death on a cross.

No, you did not wear a Fra Angelico blue cloak, no halo adorned your head

when a so-called angel brought you the message that the child in your womb was the son of God.

No, you must have been dark of hue - like the people to whom you belong and bearing the fruit of your womb must have been hard like it is for outcasts; whether he was conceived from illegitimate love or from the legitimate abuse of a woman.

\section{Fatherless in Galilee, God usurped him} so that he could give the weak and downtrodden the status of humanity; could lay his hands on children and draw women to him among whom he never favoured you as the Mother of God.

My journey to him was long

but only when the angels' choirs were silent and I could hear his voice;

only when the scent of incense and myrrh had faded away and I could smell the sweat and dust

of his homeless wanderings,

could I turn my back on the Child of Bethlehem and meet your son, rabbi Jeshua from Nazareth.

English translation by Yolanda Dreyer of Lina Spies' poem Ontdaan, dedicated to Andries van Aarde, and published in Tydelose gety, Protea Boekhuis, Pretoria, pp. 68-69, 2010; with permission by poet and publisher. 